quite an unnecessary amount from that small fee due to them. I am, Sirs, yours faithfully,

Cullompton, Devon, Jan. 19th, 1902. G. G. GidLey.

** Our correspondent, when making his annual return for income-tax purposes, must include his income "from all sources," that from his appointment as medical officer included. He may claim the repayment of the duty deducted by the Post Office authorities (provided, of course, that he has paid income-tax on the return made by him), and should direct his claim for repayment to the Secretary, Inland Revenue (Repayment Branch), Somerset House, W.C. We presume his statement "every Christmas quarter" at $1 s .2 d$. in the $\&$ refers to last Christmas only.-Ev. $\mathbf{L}$.

\section{THE SANATORIUM TREATMENT OF CONSUMPTION.}

To the Editors of THE LANCET.

SrRs,-A few words will suffice in dealing with Dr. Arthur Latham's references to my letter. I am informed that there is nothing to support my "deduction" that a patient must spend two or three years in a sanatorium. I never made it. I merely quoted the words of Dr. Clifford Allbutt verbatim et literatim who declared that this length of time was necessary for the obsolescence only of the disease. The attitude of Germany I have (and want) nothing to do with. Suffice it to say that Germany has had 40 years' experience of sanatoriums and has not made the progress we have who have relied exclusively on works of sanitation. Dr. Latham says that I recognise sanitary defects as the main etiological factor in consumption, and yet object to the removal of patients from such debilitating influences to the "fresh air" of sanatoriums. What I said was that, having recognised the cause, you should remove it and not the patients. I claim that the money squandered on sanatoriums which could be used for striking at the root of the trouble is badly spent. It may be that these institutions form "only one of the lines along which we have to work," but I have yet to learn that any serious effort has been made by the association at their own expense to clear away insanitary dwellings and remedy sanitary defects. The modern notion is not to trust to tried methods but to convert the earth into a mighty limbo for the aggregation of cases of infective, and so-called infective, diseases the occurrence of which could and should have been prevented. I am sorry I said something which had been already said by Sir John Burdon Sanderson. I tender that gentleman my apologies for having presumed to think in the same grooves as himself.

Now for the "fresh air" of sanatoriums. I regard it as a humiliation that latter-day "scientists" are prepared to do battle for a theory which is consumed at its own focus. The tubercle bacillus is or is not a pathogenic organism. Is it only pathogenic when it is desired to terror-strike governments into the passing of compulsory laws? to obtain powers for the wanton destruction of the country's foodstuffs ? to intimidate municipalities? and does its pathogenicity stop at the doors of the sanatorium? Does the circulus vitiosus become converted into an angelic halo when once the patient has taken up his abode? I leave Dr. Latham's assertion that in the midst of the coughing and spitting sanatorium crowd there are considerably fewer tubercle bacilli than in an ordinary dwelling to the judgment of your readers. The bactericidal properties of the sunshine which, of course, finds its way into all sanatoriums, even in our triste climate during the winter months, prevents the "spread of infection," \&c. One wonders if, in addition to forming a corner in fresh air, the association has taken out Royal Letters Patent for the exclusive manufacture of sunshine during the winter months. But this organism, the pathogenicity of which justifies sanitarians in demanding the most preposterous restrictions, leaves the medical and surgical staffs of Brompton Hospital severely alone, although tubercle bacilli are found there in enormous numbers. It does not touch the stationary inhabitants of health resorts frequented by consumptives, although these poor creatures in search of health are hunted from place to place, forbidden to land, and shut out of hotels by the panicmongering of public health enthusiasts who are supposed to take a kindly interest in their fate. The theory of the infectivity of consumption shares with the "endogenous sporeformation" theory the honour of being a means to an ignoble end. When the assertion that spitting at large constituted a terrible public danger was referred back to the scientists who had proclaimed that exposure to one minute's sunlight killed the tubercle bacillus we were told that the real danger lay not in the bacilli, but in their practically indestructible spores, which delectable theory left a distracted world without means of escape. It was not necessary that these spores should ever have been seen. The new method of philosophising is to start a theory and then invent facts to fit it. In the fulness of time somebody had the courage to doubt the existence of these spores, and now the theory is given up. I am advised to apply to one of the London isolation hospitals for a refutation of my argument. that aggregation is bad. I shall there learn that "thesequelæ and complications compare favourably with thosewhich obtain in ordinary houses." Secondary infection and post-scarlatinal diphtheria never do obtain in ordinary houses. They are the fruits of aggregation solely. I can assure Dr. Latham that he will have to look beyond these islands-beyond the continent of Europe-before he findsany evidence which will justify the existence of the aggregation hospital.

Now if a patient of the so-called isolation hospital falls a victim to secondary infection during a residence of a few weeks, how shall the sanatorium patient escape who is kept within striking distance of the cause of his disease for two or three zears? If the organism does not strike there can be but one explanation, which is that it is powerless to strike and the theory of infection cannot be logically held. To enter into the pretence that there is some skill in sanatorium treatment which cannot be acquired by a man of average intelligence without serving an apprenticeship deserves to be called by a name which describes it passing. well.

There is no more need for large "special" hospitals than for "special" physicians. The Nordrach Institution had a world-wide reputation while its construction was primitive in the extreme, consisting of a pair of villas with an old, disused factory as an addendum.

A word in conclusion. The profession will do well to adopt an even more cautious attitude than usual towards published sanatorium statistics. We heard the other day of 14 out of 40 sanatorium "cured" patients being dead and one in extremis within 12 months of their discharge. The figures were published by patients' friends-not by the authorities of the sanatorium.

I am, Sirs, yours faithfully,

Nottingham, Jan. 16th, 1902. Eow ARD DEAN MarRiotr.

\section{"MUNICIPAL AUTHORITIES AND THE FEEDING OF INFANTS," AND "THE INFLUENCE OF MATERNAL FACTORY LABOUR ON INFANT MORTALITY."}

\section{To the Editors of THE LANCET.}

SIRS, - In preparing the numbers of Vol. CLXI. of THE LANCET for binding I notice an annotation under the first of the above headings at p. 608 of your issue of August 31st, 1901, and at p. 814 of that of Sept. 21st, 1901, a letter by the health officer of Norwich (Dr. H. C. Pattin), to which, by your indulgence, I desire to make brief reference. In your annotation you characterise the circulation at Norwich and Darwen of a leaflet on the subject of infant feeding as a "most salutary precedent," whilst Dr. Pattin in his communication refers only to those issued at Nottingham, Newington, and by the National Health Society. Permit me to observe that this Norwich "precedent" is (like the present letter) a somewhat belated one, as for many years most excellent leaflets on this subject have been circulated by the Corporation and Sanitary Association of Manchester. and also by the East London Hospital for Children and the Liverpool: Infirmary for Children. In addition, the Corporation of Stockport in 1899 widely circulated a similar publication which had been edited by the local medica society; hence your allusion to the Norwich and Darwem circulars as a "precedent" is unintentionally, but obviously, inaccurate. Let me also at once say that I am quite sure Dr. Pattin had no wish to ignore what has been done elsewhere and was no donbt unaware of it, though in regard to Stockport the facts are alluded to in the British Medical Journal of June 2nd, 1900, p. 1388, and 